IZA DP No. 8244

Data for Studying Earnings, the Distribution of Household Income and Poverty in China

Björn Gustafsson

Li Shi

Hiroshi Sato

June 2014 


\title{
Data for Studying Earnings, the Distribution of Household Income and Poverty in China
}

\author{
Björn Gustafsson \\ University of Gothenburg \\ and IZA \\ Li Shi \\ Beijing Normal University \\ and IZA \\ Hiroshi Sato \\ Hitotsubashi University
}

Discussion Paper No. 8244

June 2014

IZA

P.O. Box 7240

53072 Bonn

Germany

Phone: +49-228-3894-0

Fax: +49-228-3894-180

E-mail: iza@iza.org

\begin{abstract}
Any opinions expressed here are those of the author(s) and not those of IZA. Research published in this series may include views on policy, but the institute itself takes no institutional policy positions. The IZA research network is committed to the IZA Guiding Principles of Research Integrity.

The Institute for the Study of Labor (IZA) in Bonn is a local and virtual international research center and a place of communication between science, politics and business. IZA is an independent nonprofit organization supported by Deutsche Post Foundation. The center is associated with the University of Bonn and offers a stimulating research environment through its international network, workshops and conferences, data service, project support, research visits and doctoral program. IZA engages in (i) original and internationally competitive research in all fields of labor economics, (ii) development of policy concepts, and (iii) dissemination of research results and concepts to the interested public.
\end{abstract}

IZA Discussion Papers often represent preliminary work and are circulated to encourage discussion. Citation of such a paper should account for its provisional character. A revised version may be available directly from the author. 
IZA Discussion Paper No. 8244

June 2014

\section{ABSTRACT}

\section{Data for Studying Earnings, the Distribution of Household Income and Poverty in China*}

This paper discusses data used in publishing statistics on earnings, the distribution of household income and poverty in China by the National Bureau of Statistics (NBS) which is widely used by policy makers, international agencies and researchers. Unlike many other countries, China until recently had a dual system of household surveys - one rural and one urban. This has had consequences for providing official data on wages, income and poverty which we discuss along with other challenges. Since the end of the 1980s, researchers have been active in the construction of large databases aimed at mapping earnings, household income and poverty, and we present seven of these in the paper.

JEL Classification: C83, D31, I32, P36

Keywords: earnings, income, inequality, poverty, data, China, National Bureau of Statistics

Corresponding author:

Björn Gustafsson

Department of Social Work

University of Gothenburg

P.O. Box 720

SE 40530 Göteborg

Sweden

E-mail: Bjorn.Gustafsson@socwork.gu.se 


\section{Introduction}

How does China's rapid economic growth affect individual and household well-being? Looking at the big picture, there is consensus that after economic reform was initiated three decades ago, China's rapid economic growth has taken a very large number of households and persons out of poverty. There is also consensus that during the same period China has become a more unequal society. However, answers to more detailed questions are open for discussion and might depend on the concept and variable in focus, period studied, and in some cases, data used. Examples of such questions are: How have earnings and earnings inequality among the urban population developed? How large is the gender wage gap and how has it developed? How large is the income gap between urban and rural areas, and between different regions of China? Which groups in the population are more likely to be poor and what kinds of changes in poverty over time can be observed? Researchers and other observers can offer some answers to these questions by consulting statistical information available in official publications and on web pages. One task of this paper is to provide a brief introduction to the statistical system for monitoring earnings, income and poverty in China as well as to discuss some of its limitations and challenges.

Before reform began at the end of 1970s, researchers interesting in making empirical studies on earnings, the distribution of household income and poverty in China did not have access to microdata. Since then the situation has changed radically and a large number of studies based on such data can now be found in the literature. This has been made possible by researchers being given the opportunity to work with microdata. The National Bureau of Statistics (hereinafter referred to as the NBS) has collected the data. Other data are the fruits of researchers' initiatives of collecting surveys covering large parts of China. The first academic studies on the topics we cover here were based on single cross-sections of data. When the data collection was repeated it became possible to address questions on changes over time. One highly interesting development concerning survey design is that of collecting panel data for households and individuals. This allows analysts to ask new questions and make new types of analyses. Examples include studies aiming at understanding the duration of poverty and reasons for moving into and out of poverty. Panel data also puts the analyst in a better position when trying to find causes and effects of differences in earnings, income, and poverty. Another task of this paper is to introduce databases with microdata which researchers can access relatively easily for conducting empirical studies.

The rest of the paper is laid out as follows: The next section presents how the system of official statistics in China collects information on earnings, household income and poverty. Section 3 discusses some other official data sources. The topic for Section 4 is microdata that is the outcome of researchers' activities. The paper ends with concluding comments.

\section{Household income data collected by NBS $^{1}$}

\footnotetext{
${ }^{1}$ This section builds partly on Gustafsson and Li (2006).
} 
Most countries in the world have official statistical systems which produce and publish information on the populations in which they operate. In the People's Republic of China the NBS (earlier known as the State Statistical Bureau, SSB) is responsible for countrywide reporting and has counterparts in each of the 22 provinces, 4 municipalities and 5 autonomous regions. There are also statistical authorities at the sub-province level. The province level statistical bureau is not only responsible for collecting data, but also for publishing information for the jurisdiction in which it is active. A researcher interested in the economic and social situation of one single province is therefore advised to consult the publications from the particular province level unit. We will start with some broad remarks on what characterises household data collected by the NBS. After that, and in somewhat more detail, we will discuss the system of collecting data from households on income, a system which has recently changed.

For researchers, the strategy of working with data already collected by the NBS can be advantageous in many respects. Statistical bureaus typically have a long-term commitment to their work leading to their being experts at all stages of the data gathering process, which thus gives them an advantage over individual researchers or research groups. Added to this is the fact that the NBS statistical system covers the entire country. In many countries, a division of labour exists between the statistical agency collecting data and publishing descriptive reports, and persons in academia who work with deeper analyses. Where this occurs, routines are in place for giving researchers access to the data collected by the statistical agency. However, such a description does not fit China where requests for access to microdata appear to be handled on a case by case basis. Initially, access was typically given to only one or a small number of regions, making it difficult to judge to what extent results could be generalised to large parts of China. ${ }^{2}$ However, more recently there are examples of research groups that have been successful in gaining access to microdata from the NBS covering large parts of China and for a substantial number of years. ${ }^{3}$

How well do the NBS and its regional counterparts succeed in producing impartial, high quality and easily assessed information? These are ideals for statistical bureaus in any country, and on these broad questions we will only offer a few comments. We note that a primary motivation for creating a statistical bureau is that the government should not be able to manipulate statistical information. However, the separation from the political leaders and their staffs can never be complete as it is the government which defines the task for the statistical bureau and also provides its resources. This is true for statistical bureaus around the world whose staffs know that some results are more welcome than others which can lead to self-censorship.

The degree of data quality is the outcome of all steps in the data production process: sampling, construction of instruments, fieldwork, coding and editing the data. Our subjective impression from having contact with NBS staff for some time is that they have high ambitions at every step of the process. Unfortunately, however, NBS has not produced many documents describing the various

\footnotetext{
${ }^{2}$ See for example Tsui (1998), Yang (1999), McCulloch and Calandrino (2003), Kung and Lee (2001), Aaberge and Li (1997), Aaberge and Zhu (2001), Coady and Wang (2000) and Fang et al (2002).

${ }^{3}$ See for example Zhang et al (2005), Li et al (2006), Chi and Li (2008), Meng (2012) and Meng et al (2013). 
steps in detail and it is therefore difficult to make a detailed and qualified evaluation of the datagenerating process. International standards for compiling macroeconomic statistics used to produce information on GDP, for example, have existed for many years. China has now adopted the System of National Accounts (SNA) meaning that such information is internationally comparable, to a large degree. In contrast, comparability across countries on earnings and income data collected at the household level is lower than in national income data, although some international recommendations exist. ${ }^{4}$

China differs from most other countries, however, in that institutional arrangements for rural and urban areas are rather different. The Hukou system was introduced in the late 1950s as an integrated part of the planning system and does not only register a person as rural or urban, but also has large implications for his or her well-being. Many public policy measures have long prioritised urban persons who are also holders of an urban hukou. People living in the cities live a different life than their peers in the rural areas. ${ }^{5}$ This is the background for why China has long had a Rural Household Survey covering rural areas and an Urban Household Survey for the urban areas - not a unified system. For these surveys the statistical bureaus in each province level unit draw one sample for rural households and another for urban households to collect information to produce the national statistics. When doing this the statistical bureaus have used different forms for rural and urban areas and definitions of certain key variables have also differed between urban and rural areas. However, as ever larger numbers of people holding a rural hukou live in urban areas, such a separation of the people into two categories has become increasingly problematic. As we will discuss further, this has motivated recent changes in the system of collecting household data.

One consequence of the differences in data collection between rural and urban areas is that up to now, it has been difficult to find official statistical descriptions that refer to the entire Chinese population. While the NBS has published results on income inequality in rural areas and urban areas separately, the agency for many years did not publish information on the extent of income inequality in China as a whole. This was highly problematic, as all evidence indicates that much of the inequality in China as a whole is due to the large income gap between urban and rural areas. ${ }^{6}$ However, as we will further discuss later in this section, the NBS recently published a time series of Gini coefficients for China as a whole.

Furthermore, the old household income survey system has meant that people with a rural Hukou permanently living in urban areas, the long-term rural-urban migrants, were more unlikely to be covered by either rural or urban surveys. As restrictions for rural people to live in urban areas were strong during the planning époque, this might have been a relatively minor problem at the time. However, since China started to move towards a market economy, ever larger numbers of rural residents have moved into the cities where some intend to stay temporarily, but many remain for an extended period (see for example Chan, 2012). Typically, such persons find jobs, but they are paid

\footnotetext{
${ }^{4}$ See Canberra Group (2011).

${ }^{5}$ See for example Chan (2009) or Whyte (2010).

${ }^{6}$ See for example Sicular et al (2007) and Li and Luo (2010). 
less than urban residents. From this follows that all official statistics on income probably overestimate average household income among persons actually living in urban areas. Furthermore, income inequality among persons who actually live in the cities might be biased. It is a great challenge for the statistical agencies now making efforts to include migrants in their household surveys, as by definition the migrants cannot be identified in official registers.

It is an intriguing task to collect statistical information on migrants in China for several reasons. There are issues of definition. For example: What distinguishes migration from commuting? Migration can be characterised by origin and destination as well as by hukou status. There is the issue of how to sample migrants at the destination where some have accommodation similar to urban residents while others live, for example, on construction sites. As migration typically is temporary, it is by and large difficult to collect panel data on migrants. However, such problems have not hindered researchers in collecting data on earnings and income among migrants in China. ${ }^{7}$

Having two systems for collecting income information, one for rural households and another for urban households, gives rise to a particular kind of problem. While the designations of rural and urban locations in China are fixed at one point in time, they are subject to change. As people move into the cities and buildings are constructed on what was previously farmland, rural locations can receive urban status. As such changes are not frequent during a one-year period, they should have little effect on how to interpret year-to-year changes in household income. However, this may not necessarily be the case regarding long-run changes.

It is noteworthy that the NBS has recently released current and retrospective estimations of Gini coefficients of per capita household income at the national level based on the official urban and rural household surveys. National Gini coefficients for per capita disposable income officially announced by the NBS are 0.473 in 2013 and 0.474 in 2012 (NBS 2013, NBS 2014). Retrospective estimation of Gini coefficients for previous years were also recently published (NBS 2013). ${ }^{8}$ The current and retrospective estimation of national Gini coefficients by the NBS is a very important reference of inequality in China because the NBS has tried to integrate the urban-rural dual survey system with the new "urban-rural integrated" sampling framework employed in the end of 2012 (discussed below), by utilizing information from the preliminary data and population census data (Wang 2013). When estimating the national Gini coefficients, the NBS also used the data from personal income tax records to correct downward bias of estimation.

We will now discuss in more detail how households were previously sampled in the rural and urban household surveys. Generally, the strategy by the NBS of sampling households and individuals was

\footnotetext{
${ }^{7}$ Gustafsson and Li (2006) describes six early surveys. In Section 4 we describe RUMiC which since 2007 has studied rural to urban migrants in China.

${ }^{8}$ Retrospective figures are 0.479 for $2003,0.473$ for $2004,0.485$ for $2005,0.487$ for $2006,0.484$ for $2007,0.491$ for 2008, 0.490 for 2009, 0.481 for 2010, and 0.477 for 2011. Xie and Zhou (2014) report that estimates of the Ginicoefficient for 2010 - 2012 based on researcher initiated surveys presented in Section 4 that are all higher. It is a task for future research to analyze the reasons for such differences.
} 
to apply a multi-stage probability sampling approach, striving for the information to be representative at the province level. Some Chinese provinces have the population size of a country, and statistical bureaus in such provinces draw additional samples for producing more detailed information which is published in the statistical yearbook of the province. In rural areas counties were chosen after categorizing all counties in a province by average income. Choosing villages in each county followed the same method. In each village the target was to survey 10 households. In 2010, for example, not fewer than 74000 households from 869 counties were chosen (NBS, 2011). A household chosen for the rural survey was included for a period of typically five years after which it was rotated out. The rural households were not only asked to provide detailed income information by bookkeeping, but also to keep detailed records of their expenditures as well. While the rural survey assembled information on the demographic characteristics and the education of each household member, it also asked each household member questions on earnings which can only be attributed to each of the household members. Many thousands of assistant enumerators were involved in helping the households keep good records.

Household samples for the Urban Household Survey were drawn from a large sampling frame of households having an urban Hukou. A two-stage stratified systematic random sampling scheme was applied. In the first stage, cities and counties were classified into five categories by population size in each province. They were then grouped into six administrative regions. In each administrative region the cities and counties were arranged by average wages of staff and workers in the urban area. Based on this classification, cities and counties were selected by a systematic sampling scheme. At the second stage, sample households were selected at city or county level. For 2010, for example this resulted in 66000 households in 474 cities being selected by the NBS (NBS, 2011).

Households selected for the Urban Household Survey typically remained for a period of three years after which they were rotated out. As in rural areas the households were regularly visited by an enumerator who asked questions and assisted in bookkeeping. As in urban areas, the respondent and his or her household had to record all income and expenditures in a very detailed way. For example, questions on earnings were put to each person in the household and the answers constituted the basis for tables published by the NBS. However, as is true for the rural survey, the urban survey did not include questions on household wealth. The system of separate rural and urban surveys was used in China until the end of 2012 when a new system was initiated. ${ }^{9}$

Before turning to how the household surveys have been reformed, we will discuss the type of information that is collected by the NBS in the household income surveys (previously as well as presently). During the planning époque, almost all workers in urban China were employed by State Owned Enterprises or by Collective Enterprises. A substantial part of workers' compensation was given in kind: goods, access to very low-price housing, etc. Such compensation was typically not included in the definition of household income applied by the NBS which can be seen as a

\footnotetext{
${ }^{9}$ Much of our description is also adequate for how the household income systems worked during the 1980s and 1990s. For more detailed information on the situation for those decades see Chen and Ravallion (1996:26-31) and Bramall (2001). 
substantial weakness. However, as many of these benefits have been phased out, the problem of under-recording has become much smaller over time (Li and Zhao, 2003). In contrast, China's transformation has led to a rapid increase in home ownership in urban areas. It is true to say that among economists there is consensus that imputed rents from home ownership should constitute a component of household income (although methods for its implementation differ). However, such a strategy is not taken by the NBS.

In defining household income the NBS has not included the value of benefits in kind received from employers nor imputed rent from owner-occupied housing when compiling the information the agency publishes. However, researchers at times have tried to include such income components to come closer to the real situation. As a consequence, one cannot expect to find full agreement between what such sources report and what the NBS publishes. This is the case not only regarding income and income inequality at one point in time, but also on their changes over time. There is also the issue of comparability across time in the published series. The income concept adopted by the NBS when preparing the published tables has been broadened over time - a fact that should be regarded as progress. However, as a side effect, comparisons over time might have been affected. Thus one (unknown) part of the recorded increase in average income of Chinese households is not real, but due to changes towards an improved definition of disposable income.

It is this kind of information collected in the statistical system that is used for tables in the statistical yearbooks of China. For example, the widely cited rates of poverty in rural China are obtained by comparing the household's income with a cut-off. The poverty line for rural China was long set at a very low level, for example at 627 Yuan per person per year in 2002. Starting in 2000 the NBS also applied a "low income line" which for 2002 was set at 869 Yuan per person per year. A new poverty line set at 2300 Yuan (in 2010 constant prices) per person per year was introduced in 2011. This poverty line is close to a 1.75 dollar per day poverty line in PPP meaning that it is in the range of the two world poverty lines (set at 1.25 USD alternatively 2.00 USD in PPP per person and day) that the World Bank often uses today when reporting on the development of poverty worldwide. ${ }^{10}$ Based on this poverty line, in 2011 the number of poor in rural China was 122 million, equivalent to 12.7 percent of the rural population. In contrast, in its monitoring of urban poverty, the NBS does not regularly publish poverty rates for urban China and there are no official statistics on the extent of poverty in China as a whole.

The coexistence of different household survey schemes between urban and rural populations has increasingly been inappropriate for understanding the actual socioeconomic conditions in China. In addition to the vast flow of rural-urban migrants, many regions have carried out Hukou system reform unifying urban and rural hukou registration. In such regions, all household members have been newly registered into the resident Hukou (jumin hukou). Against this background, the NBS has recently started a significant alteration in the structure of household income surveys, which is called reform of household survey for "urban-rural integration" (chengxiang zhuhu diaocha yitihua gaige).

\footnotetext{
${ }^{10}$ However, note that while NBS bases its estimate on rural poverty on household income, the World Bank typically makes its assessments based on household consumption.
} 
The new household survey scheme was announced in 2012 and has been in effect from 2013 on. Ma Jiantang, the director of the NBS, states that the aim of the reform is to build a unified, nationwide household survey system that can represent changes in urban-rural, interregional, and inter-sector income disparities and inequalities between different social groups (Ma 2012).

According to Ma (2012) and other related materials, the major points of this reform can be summarized as follows: First, the separate urban and rural sampling frames will be unified into one national sample frame by building primary sampling units based on the 2010 Population Census. This means rural-urban migrant households are to be incorporated into the regular sampling frame for the first time. In addition, distribution of city/county surveys is to be adjusted to reflect recent changes in geographical structure of population caused by the vast labour migration. Second, statistical indicators, which have not been comparable for urban and rural surveys, are to be unified. For example, "disposable income" ("kezhipei shouru") instead of "net income" (chunshouru) is to be used as the basic indicator for rural household income. ${ }^{11}$ Indicators of transfer income/expenditure are to be re-examined to more accurately reflect the impact of social security and other public policies. Incorporation of imputed rental income of owner-occupied housing is treated as another important issue. In addition, unification of rural and urban income indicators naturally requires reconsideration of in-kind income and expenditures (especially services) of urban households.

This reform is certainly an important milestone in the NBS household survey system. However, since relevant data collected through the "urban-rural integrated" scheme has not yet been published, it is unclear to what degree the new scheme will change the overall picture of China's income distribution. The perhaps most important issue will be the coverage of migrants. Considering the high mobility of migrants and difficulty in incorporating single migrating households into a household survey system, it might be necessary to conduct a complementary survey scheme for migrants (or for single households generally) in the future. Another issue is to what degree longitudinal comparability of published data is secured after 2013.

After having discussed the progress in the household income system in China which is accomplished by urban-rural integration, we will comment here on problems that the reform scarcely will be able to solve. Common to statistical authorities in other countries, the NBS faces the problem of a number of households not being willing to participate in their surveys, see for example Gibson et al (2003). A related problem is that not all incomes might be recorded in the surveys. Most likely, non-response and underreporting lead to inequality in income being underestimated. ${ }^{12}$ Another not trivial issue of relevance to discuss is the fact that China is a very large country and prices differ across its territory. One can therefore argue that it is meaningful to correct statistical information on earnings and income by a spatial price index. While this is not

\footnotetext{
${ }^{11}$ Specifically, public transfer expenditures and interest payments of rural households which are not deducted in "net income", should be deducted in disposable income.

${ }^{12}$ There has been considerable discussion in recent years about the underreporting of income of urban high-income groups in China, sometimes referred to as "gray income", see Luo et al. (2011) and Wang (2010). 
done in the information published by the NBS, some researchers are doing this using a spatial index developed by Brandt and Holz (2006).

The present international discussion on how best statistical agencies can measure economic performance and social progress is greatly inspired by the report of Joseph Stiglitz, Amartya Sen and Jean-Paul Fitoussi commissioned by French president Nicholas Sarkozy published in 2009 (Stiglitz et al, 2009). We cannot judge whether this report has had or will have implications on the statistics the NBS collects and publishes. However, related to the issue of providing statistics that measure the household's well-being and gender differences, one can for example note that the NBS conducted a study for 2008 on how households spend their time, in a manner allowing for international comparisons. $^{13}$

\section{Other household data collected by the NBS or other public organisations ${ }^{14}$}

In this section we will discuss some other household data collected by the NBS and other public organisations that have a somewhat different focus than the household income surveys. Much of China's poverty-alleviation strategy has for some time been directed towards officially designated rural poor areas. This provides the background for why since 1997 the NBS monitors rural poverty by the Rural Poverty Monitoring Survey (nongcun pinkun jiance diaocha). This survey focuses on all nationally designated poor counties (592 counties) and covers 54000 sample households distributed throughout 5400 villages. Aggregated data on household income and expenditures and poverty-related indicators such as poverty head count ratio have been published annually in the Rural Poverty Monitoring Report (Rural Survey Department of NBS 2011). Although sample households of this survey are not representative of the entire rural poor population, the survey is useful for tracing changes in economic conditions of households living in counties with special policy treatment. ${ }^{15}$

In order to deal with increasing mobility of the population, the NBS launched the National RuralUrban Migrant Monitoring Survey (quanguo nongmingong jiance diaocha) at the end of 2008. This survey is a quarterly-based sampling survey of the rural labour force. The survey's purpose is to capture out-migration flow at the place of origin. Its sampling frame includes more than 7500 villages in 899 counties in 31 province level administrative units and covers approximately 200000 rural labourers. It is conducted among the same households selected by the regular rural household survey. Aggregated data containing volume of out-migrants, distributions of places of origin and

\footnotetext{
${ }^{13}$ see http://australian-time-users-group.org/assets/docs/chinese-tus08.pdf

${ }^{14}$ Cook and Keeley (2007) provide information on an additional number of data sources which are not covered here.

${ }^{15}$ For a detailed introduction of the Rural Poverty Monitoring Survey and empirical analyses of rural poverty using the survey, see Yue et al. (2007).
} 
destinations, and individual characteristics of out-migrants such as gender, age, and education are published annually (NBS 2012).

Among other data with relevance for studying people's well-being produced and published by the National Bureau of Statistics, one can mention that since the mid-1980s the NBS has conducted large-scale population surveys during inter-census years, typically in the $5^{\text {th }}$ year after a population census. The 2005 One-Percent Population Survey is the latest such survey. It includes more detailed information related to demographic, geographic, economic, and housing information than the censuses provide. This large sample survey is useful for studying migration flows, for example, but the income information is limited to monthly earnings (NBS 2007).

Several countries have conducted regular labour force surveys for many years, from which statistics on employment rates and unemployment rates are regularly derived. China does not belong to such a category and no long time series on the unemployment rate based on household surveys in urban areas has been published. However, international scholars in cooperation with the Institute of Population and Labour Economics at the Chinese Academy of Social Sciences have in cooperation with the local NBS carried out the China Urban Labour Survey (CULS) for the years 2001, 2005 and 2010. ${ }^{16}$ Recently the Department of Sociology at Sun Yat-sen University launched the China Labor Force Dynamics Survey (CLDS) to monitor labour market dynamics among Chinese adults. The survey includes households in most provinces of mainland China. ${ }^{17}$

Other public agencies in China also produce statistics of relevance for judging the well-being of Chinese households and their members. Among such data most frequently referred to by researchers is the Rural Fixed Observation Points Survey (nongcun guding guanchadian) conducted by the Ministry of Agriculture since 1986. ${ }^{18}$ This survey is a longitudinal survey of villages as well as rural households and currently covers 23000 households living in 360 villages distributed in 30 province level administrative units excluding Tibet. The sampling of the survey is as follows: firstly, counties belonging to high-, middle-, and lower-income categories are selected, and secondly, "representative" villages are selected in each sample county. In the next step 40-120 households are selected in each village depending on village size. In addition to regular annual surveys on households and villages collecting basic information such as land utilization, labour inputs, agricultural production, income, and expenditures, other surveys focusing on specific issues are

\footnotetext{
${ }^{16}$ These surveys cover each of the years' five provincial capital cities (Shanghai, Wuhan, Shenyang, Fuzhou and Xi'an). For 2005 (but not subsequently), seven municipal cities were added (Wuxi, Yichang, Benxi, Zhuhai, Shenzhen, Baoji and Daqing). Guangzhou was added to the 2010 survey. Separate samples of persons with urban residence status and with migrant status were derived using a two-stage procedure; first by area, thereafter households were selected and interviewed. For further information see Giles et al (2005) and Gao and Smyth (2012).

${ }^{17}$ See http://css.sysu.edu.cn/Data . One study mapping labour force participation and unemployment in urban China using CHIP-data presented in the next section is Liu (2012).

${ }^{18}$ From the early 1990s, the survey is jointly managed by the Ministry of Agriculture and the Policy Research Office of the Central Committee of the Communist Party of China. The survey is managed by the Research Centre for Rural Economy (RCRE) at the Ministry of Agriculture. 
carried out intermittently. Aggregated data of regular annual surveys are published (see for example the Policy Research Office of the Central Committee of the Communist Party of China and the Ministry of Agriculture 2001). Microdata of the surveys is also utilized in the literature on rural household income, poverty, and on other issues of the rural economy. ${ }^{19}$ Availability of data to researchers is very limited.

It can be mentioned that other public agencies also conduct similar fixed observation point-based surveys. For example, the National Health and Family Planning Commission has recently started a nationwide monitoring survey on migrant households focusing on reproductive health and economic well-being. ${ }^{20}$

\section{Researcher initiated databases ${ }^{21}$}

While data collected by the NBS is widely used by policy makers, international agencies and many researchers, it also has limitations. Some of these limitations are discussed above and we can stress that individual researchers and research groups cannot count on having access to microdata from the NBS. To the limitations already discussed one should add that in many cases the NBS does not collect information matching concepts and circumstances researchers are interested in. This provides the background for why many researchers have involved themselves in the data-collecting process. There are many examples of researchers collecting data for one geographical area at one point in time. ${ }^{22}$ Limiting the fieldwork to one location and one point in time makes the sampling strategy and data collection manageable. A limitation with such a strategy, however, is the difficulty with generalising the results to a wider territory; another is that such data typically does not make it possible to follow and analyse changes over time.

However, there are now several examples of larger research groups being involved in collecting household data covering large parts of China. Table 1 describes seven such projects by design, reference year, sampling and sample size as well as types of questionnaires used. The table also indicates the availability of surveys on characteristics of the community in which the respondents live, method of collecting income and the main host institution, and in certain cases, related data archive. Much of the data catches are cross-sectional. However, in some cases retrospective

\footnotetext{
${ }^{19}$ As for recent literature utilizing the merit of panel data characteristics, see for example, Tao et al. (2011). See Bramall (2001) for comparisons of income data of the NBS rural household survey and the fixed observation point survey.

${ }^{20}$ From 2010 on, 106 city-based fixed survey points were built (the total number of the sample is approximately 100 000). See the National Health and Family Planning Commission (2010).

${ }^{21}$ An earlier version of this section was presented at the 2012 Asian Historical Economics Conference (September 1315, 2012, Hitotsubashi University, Tokyo).

${ }^{22}$ For example, Gustafsson and Li (2006) survey 25 articles published in academic journals from 1997 to 2003 which have used such data. Subsequently, many articles using this approach to data-access have been published.
} 
questions are also posed, and there are examples of a prospective panel design. We will first present each of the seven surveys, then compare them.

\section{/Table 1 about here/}

Of the seven surveys, the first were the China Household Income Project (CHIP) and the China Health and Nutrition Survey (CHNS), both started at the end of the 1980s. CHIP was initiated by a group of international scholars and scholars who at the time were based at the Institute of Economics, Chinese Academy of Social Science, Beijing. Now it is housed at Beijing Normal University, Beijing. CHNS is a project conducted by the University of North Carolina at Chapel Hill, USA and the National Institute of Nutrition and Food Safety at the Chinese Centre for Disease Control and Prevention, China. Microdata from both are available to researchers and a large number of studies using one or the other of the two databases have been conducted and published.

CHIP and CHNS differ in several respects. As indicated by their names, CHIP is focused on household income and CHNS on health and nutrition, with less detailed income information. CHIP has taken advantage of working with the NBS in many stages of the data generating process, while this is not the case for CHNS. Households selected for the rural and urban surveys of CHIP are subsamples from the NBS's larger surveys and cover many, but not all, province level units, see Table 2. The coverage of province level units is smaller in CHNS and does not include for example, any of the four municipalities. CHNS has panel data characteristics while CHIP is a repeated crosssection survey, although some retrospective data on household income has been collected.

Being a multi-purpose survey containing rich information, CHNS has had large use outside a circle of economists. Many users of CHIP have worked with concepts of income that are broader than that adopted by the NBS in line with what is used in international studies. This has been done by including the value of benefits-in-kind received by urban households and including the imputed rent of owner-occupied housing. In the waves now available for researchers, income information refers to the years 1988, 1995, 2002 and 2007. A new wave for 2013 is in preparation as this text is being written. In the first three waves there is also information on household wealth. As shown in Table 2, all waves of CHIP consist of separate surveys on rural and urban households. The 2002 wave and the 2007 wave also include a sample of migrant households, which are not the subsample of the NBS survey. For further details see Eichen and Zhang (1993), Li et al (2008) and Luo et al (2013). Utilization of microdata from the CHIP surveys can be applied for from ICPSR and the China Institute of Income Distribution at BNU ${ }^{23}$. Microdata from CHIP 2002 has recently been made available from LIS Cross National Data Centre in Luxembourg where variable definitions as far as possible have been harmonised with similar surveys made for other countries in order to facilitate cross-country comparisons of earnings, income and poverty. ${ }^{24}$

\footnotetext{
${ }^{23}$ See for example http://www.icpsr.umich.edu/icpsrweb/ICPSR/studies/21741. The China Institute of Income Distribution can be accessed at http://www.ciidbnu.org/

${ }^{24}$ See http://www.lisdatacenter.org/news-and-events/first-chinese-dataset-in-lis/ 
The panel survey Rural-Urban Migration in China (and Indonesia - RUMiC / RUMiCI) was constructed to provide answers to questions on the impact of internal migration on income mobility, poverty alleviation, education, health and nutrition of children, and the assimilation of migrant workers in the city. ${ }^{25}$ The panel survey for China initiated by the Australian National University and Beijing Normal University has the first survey for 2008. It covers the nine largest provinces sending and receiving migrants: Shanghai, Jiangsu, Zhejiang, Hubei, Sichuan, Guangdong, Henan, Anhui and Sichuan. The design includes one urban survey, one rural survey (both conducted by the NBS) as well as one migrant survey (conducted by a professional survey organisation). ${ }^{26}$ Along with standard questions on household characteristics, special questions on education, income and migration history are included in the migrant survey.

The first wave of the Chinese General Social Survey (CGSS) refers to 2003. The survey is a collaboration between Renmin University of China and Hong Kong Sciences and Technology University, along with seven other Chinese universities. The basic structure is repeated cross sections. It contains core modules in each survey including questions on labour market and social security as well as topic modules that vary across surveys. Bian and Li (2012) provide further details on background and sample design. It is basically a sociological survey, giving much attention to subjective aspects of well-being including questions on perception of income inequality.

Recently, two nationwide panel surveys were launched by the Institute of Social Science Survey (ISSS) at Peking University. The first survey is the China Health and Retirement Longitudinal Study (CHARLS) and the second is the China Family Panel Study (CFPS). The CHARLS aims to collect nationally representative data of middle-aged and elderly individuals and families. After the pilot survey in Zhejiang and Gansu in 2008, the first nationwide baseline survey of CHARLS was conducted in 2011-2012 and the second in 2013. These cover approximately 17500 individuals of 100000 households distributed in 150 counties/districts of 30 province level administrative units. ${ }^{27}$ In addition to its panel data characteristics, the survey is unique in its focus on individuals age 45 and over and their families. An interesting aspect is that similar surveys have been carried out in other East Asian countries that share the same problem of a rapidly aging population. ${ }^{28}$

\footnotetext{
${ }^{25}$ Here we do not cover the parallel survey made in Indonesia. For further information including the Indonesian survey see http://rse.anu.edu.au/rumici/. Akguc et al (2013) provides much information on RUMiC and some waves can be downloaded from the Institute for the Study of Labor, see http://idsc.iza.org/?page=27\&id=58

26 For a description of the sampling procedure see http://rse.anu.edu.au/rumici/pdf/Census\%20manual_China_English08.pdf

${ }^{27}$ As for studies based on CHARLS (pilot version), see for example Smith et al. (2012).

${ }^{28}$ Similar surveys are the Japanese Study of Aging and Retirement (JSTAR) and the Korean Longitudinal Study of Aging (KLoSA). See the relevant web sites: http://www.rieti.go.jp/en/projects/jstar/; http://www.kli.re.kr/klosa/en/about/introduce.jsp 
The CFPS was launched in 2010 after preliminary studies conducted in 2008-2009. The study covers approximately 16000 households living in 25 province level units. CFPS has taken advantage of its panel data characteristics and unique questionnaire design that combines main questionnaires (separate questionnaires for adults and children) and additional questionnaires focusing on specific population groups. The second wave of the survey was conducted in 2012 and the data from the first two surveys are available for public use. ${ }^{29}$

The China Household Finance Survey (CHFS) launched in 2011 is unique in its detailed information on household wealth including financial assets and debts, housing assets, and assets for household production and business activities (Gan et al. 2013). In addition to household wealth, the survey also collects information on income and expenditure including public and private insurances. Another distinct feature of the CHFS is quarterly-based complementary interviews on employment, assets, income, and expenditure that are designed in a two-year cycle of the main survey. The 2011 CHFS covered approximately 8400 households consisting of 29500 individuals.

We will now compare the seven researcher initialized surveys described in Table 1. Some have collected information at the community level (village, urban neighborhood) simultaneously with household data. Since household economic behavior and its outcomes are affected not only by macro and regional economic conditions, but by economic and sociopolitical contexts at the community or small-region level (see, for example, Treiman 2009), it will be useful to employ a multilevel research framework by combining microdata and community-level/small-region data. The CFPS employs a multilevel survey design and includes both urban and rural community surveys (residence committee and administrative village). CHNS has included community questionnaires from the start of the project. CHIP began to include a rural community (administrative village) questionnaire from the 2002 wave on. The 2007 wave of CHIP also includes an urban community (residence committee) survey to best capture the relationship between migrants and local urban residents. As for data provided by an official agency, the rural fixed observation-point survey (see Section 3) applies a multilevel framework.

Regarding survey design and sampling frame, CHIP and CFPS have the broadest spatial coverage when it comes to sampling frame and are therefore from this perspective best suited to estimate nationwide income distribution. RUMiC is designed to represent regions of origin/destination of rural-urban migrants. The sampling frame of CGSS aims to represent the adult population aged 18 and over and income is treated as a control variable rather than a focus variable. CHARLS focuses on individuals over age 45 and their families. CHNS has a narrower spatial coverage. However, as opposed to the other surveys, it consists of a long-range panel study and has collected detailed data on health, nutrition, and environmental hygiene. When using CHIP and CFPS for income distribution studies, users should consider whether to use appropriate population weights and adjustment of regional price differences (regional PPP). Although the first wave of CHFS provides broad coverage of provincial level administrative units, there might be bias caused by relatively

\footnotetext{
${ }^{29}$ The results and descriptive statistics from the surveys are presented in Xie et al. (2013). 
small sample size and some non-randomness in sampling when it is used to estimate the nationwide income distribution (Yue and Li 2013).

Concerning categories of households covered, inclusion of rural-urban migrants is the key issue. CHIP has an advantage in that it includes migrant households in the sampling frame relatively early (from the 2002 wave on). The 2007 wave of CHIP and RUMiC complement each other by using a common sampling design which covers fifteen cities distributed in nine provincial level units. ${ }^{30}$ The sampling frame of migrant households of 2007 CHIP and RUMiC surveys is based on a census survey using city maps, enabling it to cover various types of migrants including those who have an unstable working status (see RUMiC 2007 for the detailed sampling procedure). Migrant samples of the 2002 wave of CHIP are made up of those who have relatively stable working and living status and the comparison of the two waves should be conducted carefully. ${ }^{31}$

Income information is collected differently in the seven surveys. Some use a single question while others ask for particular income sources and also rely on bookkeeping. ${ }^{32}$ The latter method can be expected to provide the best information. It is applied by CHIP for its rural and urban samples. It means that the data collection takes advantage of a subsample of the NBS household survey where information on major income components is derived from bookkeeping by the respondents that have been regularly monitored by enumerators of the NBS. Additional income components are collected by supplementary interviews. The same approach is used for the urban and rural household samples of RUMiC. In contrast to these two surveys, income data in CHNS, CFPS, CHARLS, and CHFS are collected by interview only. It should also be noted that income questions of CFPS, CHARLS, and CHFS (main interview) are designed to be answered in ranges instead of absolute values to guard against "do not know" and refusal.

Some income components are more difficult to capture in a survey than others: Imputed rent of owner occupied housing, in-kind income, transfer income, and property income. We will discuss each of them, starting with the first mentioned. Along with the privatization of urban housing and the very rapid increase in housing prices, imputed rent of owner-occupied housing has increased rapidly in China and has a larger impact on overall income inequality (Sato, Sicular, and Yue 2013). However, there are problems, not unique to China, when it comes to estimating the imputed rents of

30 The cities covered are Guangzhou, Dongguan, Shenzhen, Zhengzhou, Luoyang, Hefei, Bengbu, Chongqing, Chengdu, Shanghai, Nanjing, Wuxi, Hangzhou, Ningbo, and Wuhan (RUMiC 2007).

${ }^{31}$ See Chapter 2 of Li, Sato, and Sicular (2013) for comparisons of the distribution of migrant household income and national income distribution with/without including migrant households between 2002 and 2007.

32 See, for example, Micklewright and Schnepf (2010) for the analysis of bias in income data collected by a single question. 
owner-occupied housing. Inputs in such calculations are typically based on information on market rent and/or market value of housing, both of which can be significantly biased when coming from a respondent's estimates. Amount of housing mortgage and cost of housing ownership are also difficult to collect by interview. It can be noted that data quality on market rent and market value of housing as collected in CHIP are relatively high because they reflect information on the housing market at the city level captured by the local NBS bureaus.

The inclusion of in-kind income, especially the value of goods/services for own consumption, for rural households and urban self-employed households, is another income component facing a measurement problem. It is difficult to systematically cover quantities of in-kind income from an interview. Another issue is which prices to set for goods/services households produce and also consume. In this regard, the NBS household survey has the advantage as the amounts of agricultural products are captured by bookkeeping and values are adopted by certain prices set by the NBS. ${ }^{33}$

There are also issues regarding how to measure transfer income. The most important of these is how to include income from social security and social assistance. Public transfer incomes such as pension, medical insurance, minimum living standard guarantee (Dibao), and other programs have become increasingly important both for urban and rural households. In addition, for rural households, subsidies for agricultural production (food grain production, agricultural production materials, purchasing of agricultural machines, and other local level subsidies), the subsidy for the Sloping Land Conversion Program, and other subsidies have become important income components. ${ }^{34}$ It is especially difficult to capture payments like reimbursement of medical expenses from public medical insurance programs. A careful questionnaire design is needed in order to monitor out-of-pocket expenses and their reimbursements. Finally, on the issue of income components it can be noted that as market allocation has become more and more important it has become essential to try to capture income components such as interests and dividends as well as capital gains when selling housing and stocks.

\section{Conclusions}

In this paper we have presented official data on household income as well as seven researcher initiated databases and commented on their characteristics. We have found that to a large extent the

\footnotetext{
${ }^{33}$ Although, there has been some criticism that price applied to agricultural products by the NBS is lower than market price and therefore rural household income tends to be understated until the 1990s (Bramall 2001). However, such possible bias can be considered to have become less important along with the reforms of the purchasing system of agricultural products. See also Benjamin et al (2005).

${ }^{34}$ See chapters 1 and 2 of Li, Sato, and Sicular (2013) for an overview and description of changes in public transfers in the 2000s. 
research initiated databases focus on various aspects and are thus complementary to each other. They also complement the data that the NBS collects. We conclude this paper by summarizing several basic issues that both official surveys and researcher initiated surveys need to address.

Firstly, the major challenge both for official surveys and researcher initiated surveys is how to incorporate rural-urban migrants. As discussed above, recent reform for "urban-rural integrated" household surveys initiated by the NBS is certainly an important milestone in Chinese statistical systems. Researcher initiated surveys such as recent waves of CHIP, RUMiC and CFPS have also made progress, although the transient, informal and diverse situations of migrants make it difficult to capture this population group well.

Secondly, along with increases in income level and social mobility, probable biases due to nonresponse, and underreporting of income (especially by the high-income group), which are universal issues in household surveys in other countries, will become more and more important for Chinese household data. Improvements in the operation process as well as the sampling process are needed for the NBS household survey. The NBS has already tried to improve the operation process, for example, by introducing web-based bookkeeping. Regarding possible downward bias caused by the underreporting of income of the high-income group, some studies have tried to combine household survey data with other complementary data focusing on the high-income group (Li and Luo 2011).

Thirdly, some holes are evident with respect to the kinds of household statistics that are being regularly produced and published for China. One is that there is no official labour force survey that regularly publishes information on urban employment and unemployment. Another weak area is that data on wealth is inadequate in both the NBS household survey and existing recent researcher initiated surveys. Wealth inequality has been increasingly important for the analyses of household well-being. For example, recent waves of CHIP show that imputed rent of owner-occupied housing has a strong impact on intra-urban income inequality and rural-urban income disparity (Sato et al. 2013). In addition, under the current institutional setting, inequality in wealth has most likely very strong implications for intergenerational transmission of inequality. 


\section{References}

Aaberge, R. and Li, S. (1997). "The Trend in Urban Income Inequality in Two Chinese provinces, 198690", Review of Income and Wealth, 43, 335-355.

Aaberge, R.and Zhu, Y. (2001). "The Pattern of Household Savings during a Hyperinflation: The Case of Urban China in the Late 1980s", Review of Income and Wealth, 47, 181-202.

Akguc, M., Giuletti, C. and Zimmermann, K. (2013) "The RUMiC Longitudinal Survey: Fostering Research on Labor Markets in China”, Bonn: Institute for the Study of Labor (IZA), Discussion Paper No. 7860.

Bian, Y and Li, L. (2012). "The Chinese General Social Survey (2003-8). Sample Designs and Data Evaluation", Chinese Sociological Review, 45, 70 - 97.

Benjamin, D. Brandt, L and Giles, J. (2005) “The Evolution of Income Inequality in Rural China”, Economic Development and Cultural Change, 53 (4), 769-824.

Brandt, L. and Holz, C. A. (2006). "Spatial Price Differences in China: Estimates and Implications", Economic Development and Cultural Change, 55 (1), 43-86.

Bramall, C. (2001). "The Quality of China's Household Income Surveys", The China Quarterly, 167, pp. 689-705.

Canberra Group (2011). Handbook on Household Income Statistics, Second Edition, Geneva: United Nations.

Chan, K.W. (2009) “The Chinese hukou system at 50”, Eurasian Geography and Economics, 197-221.

Chan, K.W. (2012). "Migration and Development in China: Trends, Geography and Current Issues", Migration and Development, 1 (2) $187-205$.

Chen, S. and Ravallion, M. (1996). "Data in Transition: Assessing Rural Living Standards in Southern China", China Economic Review, 7(1), 23-55.

Chi, W and Li, B. (2008). "Glass Ceiling or Sticky Floor? Examining the Gender Earnings Differential Across the Earnings Distribution in Urban China, 1987 - 2004”, Journal of Comparative Economics, 36 (2), 243-263.

Coady, D. and Wang, L. (2000). "Incentives, Allocation and Labor-Market Reform during Transition: The Case of Urban China, 1986-1990”, Applied Economics, 32, 511-526.

Cook, S. and Keeley, J. (2007). "Micro-data Scoping Study - China" Report submitted to Economic and Social Research Council U.K. Institute of Development Studies and International Institute for Environment and Development, available at http://www.esrc.ac.uk/_images/China_tcm8-5137.pdf 
Eichen, M. and Zhang, M. (1993). "Annex: The 1988 Household Sample Survey: Data Description and Availability”, in Griffin, K. and Zhao, R. (Eds.), The Distribution of Income in China, New York: St. Martin's Press, 331-346.

Fang, C., Zhang, X., and Fan, S. (2002). "Emergence of Urban Poverty and Inequality in China: Evidence from Household Surveys", China Economic Review, 13, 430-443.

Gan, L., Yin, Z., Jia, N., Xu, S., Ma, S., and Zheng, Lu. (2013). Data You Need to Know about China: Research Report of China Household Finance Survey 2012. Berlin and Heidelberg:Springer.

Gao, W. and Smyth, R. (2012) "Returns to Schooling in Urban China, 2001 -2010: Evidence from Three Waves of the China Urban Labor Survey", Discussion Paper 50 /12, Monash University, Australia available at: http://www.buseco.monash.edu.au/eco/research/papers/2012/5012returnsgaosmyth.pdf

Giles, J. Park, A. and Zhang, J. (2005). "What is China's True Unemployment Rate?" China Economic Review, 16, 149-170.

Gibson, J., Huang, J and Rozelle, S. (2003). "Improving Estimates of Inequality and Poverty from Urban China's Household Income and Expenditure Survey”, Review of Income and Wealth, 49, 53-68.

Griffin, K. and Zhao, R. (eds) (1993). The Distribution of Income in China, New York: St. Martin's Press. (Chinese edition published as Zhongguo Jumin Shouru Fenpei Yanjiu, Beijing: Zhongguo Shehuikexue Chubanshe [China Social Science Press], 1994)

Gustafsson, B. and Li, S. (2006). "Surveys - Three Ways of Obtaining Household Income Data", in Heimer, M. and Thogersen, S. (Eds) Doing Fieldwork in China, Copenhagen: NiAS Press, 129-152.

Gustafsson, B., Li, S., and Sicular, T. (eds) (2008). Inequality and Public Policy in China, New York: Cambridge University Press. (Chinese edition published as Zhongguo Jumin Shouru Fenpei Yanjiu III, Beijing: Beijing Shifan Daxue Chubanshe [Beijing Normal University Press], 2008)

Kung, J. and Lee, Y. (2001). "So What If There is Income Inequality? The Distributive Consequences of Nonfarm Employment in Rural China”, Economic Development and Cultural Change, 30, 395-414.

Li, S., Luo, C., Wei, Z., and Yue, X. (2008). “Appendix: The 1995 and 2002 Household Surveys: Sampling Methods and Data Description”, in Gustafsson, B., Li, S., and Sicular, T. (Eds.), Inequality and Public Policy in China, New York: Cambridge University Press, 337-353.

Li, H., Zhang, J, Sin, L.T., and Zhao, Y. (2006). "Relative Earnings of Husbands and Wives in Urban China”, China Economic Review, 17 (4), 412-431. 
Li, S., Sato, H., and Sicular, T. (eds) (2013). Rising Inequality in China: Challenges to a Harmonious Society, New York: Cambridge University Press. (Chinese edition published as Zhongguo Shouruchaju Biandong Fenxi: Zhongguo Jumin Shourufenpei Yanjiu IV, Beijing: Renmin Chubanshe [People's Press], 2013)

Li S. and Luo, C. (2010). "Re-estimating the Income Gap between Urban and Rural Households in China", in M. K. Whyte, ed., One Country, Two Societies: Rural-Urban Inequality in Contemporary China, Cambridge, MA: Harvard University Press, 105-121.

Li S. and Luo, C. (2011). "Zhongguo Shouruchaju Jiujing you Duoda? [How Actually Unequal is China?]”, Jingji Yanjiu [Economic Reserach], 2011-4, 68-78.

Li, S. and Zhao, Y. (2003). "The Decline of In-kind Wage Payments in Urban China," Journal of Chinese Economic and Business Studies, 1(2), 245-258.

Liu, Q. (2012). "Unemployment and Labor Force Participation in Urban China”, China Economic Review, $23,18-33$.

Luo, C., Yue, X., and Li, S. (2011). "Dui Wang Xiaolu Huiseshouru Gusuan de Zhiyi [A critique on Wang Xiaolu's Estimation of the Gray income]", Bijiao [Comparative Studies], 52, 146-158.

Luo, C, Li, S., Sicular, T.,Deng, Q., and Yue, X.(2013). The 2007 household surveys: Sampling, methods and data description, in Li, S., Sato, H. and Sicular, T. (Eds.) Rising Inequality in China. Challenges to a Harmonious Society, New York: Cambridge University Press.

Ma, J (2012). "Dali Tuijin Chengxiang Zhuhudiaocha Yitihua Gaige [The promotion of reforms toward urban-rural integrated household survey]", Zhongguo Tonji [Chinese Statistics], 2012-3, electric version, http://www.stats.gov.cn/tjshujia/zgtj/t20120331_402796201.htm [accessed in September 11, 2013]

McCulloch, N. and Calandrino, M. (2003). "Vulnerability and Chronic Poverty in Rural Sichuan”, World Development, 31, 611-628.

Meng, X. (2012). "Labour Market Outcomes and Returns in China", Journal of Economic Perspectives, 26, 75-102.

Meng, X, Sheng, K. and Xue, S. (2013). "Economic Reform, Education Expansion, and Earnings Inequality for Urban Males in China, 1988-2009”,Journal of Comparative Economics, 41, $227-244$.

Micklewright, J. and Schnepf, S. V. (2010). "How Reliable are Income Data Collected with a Single Question?", Journal of the Royal Statistical Society: Series A, 173(2), 409-429

National Bureau of Statistics (NBS) (2007). 2005 nian Quanguo 1\% Renkou Chouyangdiaocha Ziliao [The 2005 One-Percent Population Sampling Surveyl, Beijing: China Statistical Press. 
National Bureau of Statistics (NBS) (2011). Zhongguo Zhuhudiaocha Nianjian 2011 [China Yearbook of Household Surveys 2011], Beijing: Zhongguo Tongji Chubanshe [China Statistical Press].

National Bureau of Statistics (NBS) (2012). "2012 Quanguo Nongmingong Jiancediaocha Baogao [The National Rural-urban Migrant Monitoring Survey 2012]", published electrically at the official website of NBS. http://www.stats.gov.cn/tjfx/jdfx/t20130527_402899251.htm. [accessed in September 11, 2013]

National Bureau of Statistics (NBS) (2013). "Ma Jiantang jiu 2012 nian Guominjingji Yunxing Qingkuang Da jizhe Wen [Press meeting by Ma Jiantangon the national economic conditions in 2012]", published electrically at the official website of NBS. http://www.stats.gov.cn/tjgz/tjdt/201301/t20130118_17719.html [accessed in April 6, 2014].

National Bureau of Statistics (NBS) (2014). "Guojia Tongjiju Juzhang Ma Jiantang jiu 2013 nian Quannian Guominjingji Yunxing Qingkuang Da Jizhe Wen [Press meeting by Ma Jiantang, Director of NBS, on the national economic conditions in 2013]", published electrically at the official website of NBS. http://www.stats.gov.cn/tjgz/tjdt/201401/t20140120_502414.html [accessed in April 6, 2014].

National Health and Family Planning Commission (2010). "Guanyu Jiaqiang Quanyuan Liudongrenkou Tongji, Kaizhan Liudongrenkou Dongtai Jiance Gongzuo de Zhidao Yijian [Direction on improvement of comprehensive statistics of migrant population and promotion of the monitoring of population mobility dynamics]", Official Website of the National Health and Family Planning Commission, http://www.moh.gov.cn/ldrks/s3573/201306/a32678f86b2b4c35bdb1dafcca1547b3.shtml [accessed in September 12, 2013]

Policy Research Office of the Central Committee of the Communist Party of China and the Ministry of Agriculture (2001). Quanguo Nongcun Shehui Jingji Dianxing Diaocha Shuju Huibian [National Rural Socio-economic Survey Data Collection], Beijing: Zhongguo Nongye Chubanshe [China Agricultural Press].

$\begin{array}{llll}\text { RUMiCI(2007). } & \text { Rural-Urban } & \text { Migrant } & \text { Project }\end{array}$ Manual.http://rse.anu.edu.au/rumici/pdf/Census\%20manual_China_English08.pdf [accessed in march 25, 2014]

Riskin, K., Zhao, R., and Li, S. (eds) (2001). China's Retreat from Equality: Income Distribution and Economic Transition, Armonk, New York: M. E. Sharpe. (Chinese edition published as Zhongguo Jumin Shouru Fenpei Zaiyanjiu, Beijing: Zhongguo Caizheng Jingji Chubanshe [China Finance and Economics Press], 1999)

Rural Survey Department of NBS ed. (2011). Zhongguo Nongcun Pinkun Jiance Baogao 2010 [Poverty Monitoring Report of Rural China 2010], Beijing: Zhongguo Tongji Chubanshe [China Statistics Press].

Sato, H., Sicular, T., and Yue, X. (2013). "Housing Ownership, Incomes, and Inequality in China, 20022007", in Li, S., Sato, H. and Sicular, T. (eds) Rising Inequality in China: Challenges to a Harmonious 
Society, New York: Cambridge University Press.

Smith, J. P., Shen, Y., Strauss, J., Yang, Z., and Zhao, Y. (2012). "The Effects of Childhood Health on Adult Health and SES in China", Economic Development and Cultural Change, 61(1), 127-156.

Sicular, T., Yue, X, Gustafsson, B and Li, S (2007). "The Urban - Rural Income Gap and Inequality in China", Review of Income and Wealth, 53 (1), 93 - 126.

Stiglitz, J., Sen, A. and Fitoussi, J-P (2009). Report by the Commission on the Measurement of Economic performance and Social Progress, available at http://www.stiglitz-sen-fitoussi.fr/documents/rapport_anglais.pdf

Tao, R., Liu, M., Su, F., and Lu, X. (2011). “Grain Procurement, Tax Instrument and Peasant Burdens during China's Rural Transition”, .Journal of Contemporary China, 20 (71), 659-677.

Treiman, D., Lu, Y., and Qi, Y. (2009). "New Approaches to Demographic Data Collection”, California Center for Population Research On-Line Working Paper Series, CCPR-2009-022.

Tsui, K. (1998). "Trends and Inequalities of Rural Welfare in China: Evidence from Rural Households in Guangdong and Sichuan", Journal of Comparative Economics, 26, 783-804.

Wang, P. (2013) "Guanyu Woguo Juminshouru Jini Xishu Cesuan de Jige Wenti" [Several issues on the estimation of Gini coefficient of personal income in China], published electrically at the official web site of NBS. http://www.stats.gov.cn/ztjc/ztfx/grdd/201302/t20130201_59099.html [accessed in April 6, 2014].

Wang, X. (2010). Huiseshouru yu Guominshouru Fenpei [Grey Income and National Income Distribution], Bijiao, 48, 1-29.

Whyte, M.K. (2010) One Country, Two Societies. Rural - Urban Inequality in Contemporary China, Cambridge and London: Cambridge University Press.

Xie, Yu, Zhang, X., Li, J., Yu, X., and Ren, Q. (2013). Zhongguo Minsheng Fazhan Baogao [China Report on People's Livelihood Development] Beijing: Beijing Daxue Chubanshe [Peking University Press].

Xie, Y. and Zhou, X. (2014) "Income Inequality in today's China", Proceedings of the National Academy of Sciences of the United States. Published ahead of Print April 28, 2014.

Yang, D. T. (1999). "Urban-Biased Politics and Rising Income Inequality in China", American Economic Review, 89, 306-310.

Yue, X. and Li, S. (2013) Guanyu Jini Xishu Zhenglun de Huigu [A Review on the Gini Coefficient Debate], http://www.ciidbnu.org/news/201307/20130708161954706.html [accessed in February 5, 2014] 
Yue, X, Li, S., Wang, P., and Guan, B. (2007).Toushi Zhongguo Nongcun Pinkun [Perspective on Rural Poverty in China] Beijing: Jingii Kexue Chubanshe [Economic Science Press].

Zhang, J., Zhao, Y., Park, A. and Song, X. (2005). "Economic Returns to Schooling in Urban China 1988 to 2001", Journal of Comparative Economics, 33

(4), 730-752. 
Table 1Researcher-initiated databases on economic conditions of Chinese households

\begin{tabular}{|c|c|c|c|c|c|c|c|}
\hline Projects/surveys & $\begin{array}{l}\text { China } \\
\text { Household } \\
\text { Income Project }\end{array}$ & $\begin{array}{l}\text { Rural-Urban } \\
\text { Migration in } \\
\text { Indonesia and } \\
\text { China }\end{array}$ & $\begin{array}{l}\text { China Health } \\
\text { and Nutrition } \\
\text { Survey }\end{array}$ & $\begin{array}{l}\text { Chinese General } \\
\text { Social Survey }\end{array}$ & $\begin{array}{l}\text { Chinese Family } \\
\text { Panel Studies }\end{array}$ & $\begin{array}{l}\text { China Health and } \\
\text { Retirement } \\
\text { Longitudinal } \\
\text { Study }\end{array}$ & $\begin{array}{l}\text { China Household } \\
\text { Finance Survey }\end{array}$ \\
\hline Abbreviations & CHIP & RUMiC & CHNS & CGSS & CFPS & CHARLS & CHFS \\
\hline Design & $\begin{array}{l}\text { Repeated cross- } \\
\text { sections, with } \\
\text { revised modules } \\
\text { of questionnaires } \\
\text { each wave }\end{array}$ & $\begin{array}{l}\text { Panel, with a } \\
\text { new wave of } \\
\text { interviews } \\
\text { each year }\end{array}$ & $\begin{array}{l}\text { Panel (rotating } \\
\text { panel), with } \\
\text { revised modules } \\
\text { of } \\
\text { questionnaires } \\
\text { each wave }\end{array}$ & $\begin{array}{l}\text { Repeated cross- } \\
\text { sections, with } \\
\text { new modules of } \\
\text { questionnaires } \\
\text { each wave; } \\
\text { panel from } 2010 \\
\text { wave }\end{array}$ & $\begin{array}{l}\text { Panel, with a } \\
\text { new wave of } \\
\text { interviews each } \\
\text { year }\end{array}$ & $\begin{array}{l}\text { Panel, with a new } \\
\text { wave of } \\
\text { interviews every } \\
\text { two years }\end{array}$ & $\begin{array}{l}\text { A cross-section } \\
\text { has been } \\
\text { completed. }\end{array}$ \\
\hline Reference years & $\begin{array}{l}1988,1995 \\
2002,2007+\end{array}$ & $2007+$ & $\begin{array}{l}\text { 1989, 1991, } \\
1993,1997, \\
2000,2004, \\
2006,2009+\end{array}$ & $\begin{array}{l}2003,2004, \\
2005,2006, \\
2008, \quad 2010+\end{array}$ & $2010+$ & $\begin{array}{l}2011-2012, \\
2013+ \\
\text { (pilot survey and } \\
\text { resurvey 2008, } \\
2012 \text { ) }\end{array}$ & 2011 \\
\hline Sampling frame & $\begin{array}{l}\text { Rural and urban } \\
\text { samples: } \\
\text { National } \\
\text { probability } \\
\text { sample of } \\
\text { households } \\
\text { (subsample of } \\
\text { NBS's official } \\
\text { annual } \\
\text { household } \\
\text { survey) } \\
\text { Migrant sample } \\
\text { 2002: selected } \\
\text { from NBS's }\end{array}$ & $\begin{array}{l}\text { Samples of } \\
2007 \text { wave are } \\
\text { subsamples of } \\
\text { CHIP 2007. } \\
\text { Rural and } \\
\text { urban samples: } \\
\text { National } \\
\text { probability } \\
\text { sample of } \\
\text { households } \\
\text { (subsample of } \\
\text { NBS's official } \\
\text { annual } \\
\text { household }\end{array}$ & $\begin{array}{l}\text { Multistage semi- } \\
\text { probability } \\
\text { sample }\end{array}$ & $\begin{array}{l}\text { National } \\
\text { probability } \\
\text { sample of } \\
\text { people age 18- }\end{array}$ & $\begin{array}{l}\text { National } \\
\text { probability } \\
\text { sample } \\
\text { (excluding } \\
\text { ethnic minority } \\
\text { autonomous } \\
\text { districts in } \\
\text { western region) }\end{array}$ & $\begin{array}{l}\text { National } \\
\text { probability } \\
\text { sample of people } \\
\text { age } 45 \text { and over }\end{array}$ & $\begin{array}{l}\text { Multistage semi- } \\
\text { probability sample }\end{array}$ \\
\hline
\end{tabular}




\begin{tabular}{|c|c|c|c|c|c|c|c|}
\hline & $\begin{array}{l}\text { preparatory } \\
\text { census data for } \\
\text { annual urban } \\
\text { household } \\
\text { survey, } \\
\text { including only } \\
\text { long-term, stable } \\
\text { migrants } \\
\text { Migrant sample } \\
\text { 2007: survey } \\
\text { team's own } \\
\text { sampling } \\
\text { through using } \\
\text { equal area } \\
\text { sampling using } \\
\text { street maps of } 15 \\
\text { cities, including } \\
\text { both long-term } \\
\text { stable migrants } \\
\text { and temporary } \\
\text { migrants. }\end{array}$ & $\begin{array}{l}\text { survey) } \\
\text { Migrant } \\
\text { sample: survey } \\
\text { team's own } \\
\text { sampling } \\
\text { through using } \\
\text { equal area } \\
\text { sampling } \\
\text { using street } \\
\text { maps of } 15 \\
\text { cities. }\end{array}$ & & & & & \\
\hline Sample size & See Table 2 & $\begin{array}{l}2007: \\
\text { approximately } \\
5000 \text { urban } \\
\text { households } \\
\text { and } 8000 \\
\text { rural } \\
\text { households, } \\
\text { and } 5000 \\
\text { migrant } \\
\text { households. }\end{array}$ & $\begin{array}{l}\text { Approximately } \\
4400 \\
\text { households, } 19 \\
000 \text { individuals }\end{array}$ & $\begin{array}{l}2003: 5894 \\
\text { (urban only); } \\
2004+ \\
\text { approximately } \\
10000 \\
\text { individuals } \\
2010+ \\
\text { approximately } \\
10000 \\
\text { individuals }\end{array}$ & $\begin{array}{l}\text { Approximately } \\
16000 \\
\text { households }\end{array}$ & $\begin{array}{l}\text { Approximately } 17 \\
500 \text { individuals of } \\
10000 \\
\text { households, }\end{array}$ & $\begin{array}{l}\text { Approximately } \\
8400 \text { households, } \\
29500 \text { individuals }\end{array}$ \\
\hline \multicolumn{8}{|l|}{ Questionnaire } \\
\hline $\begin{array}{l}\text { Urban } \\
\text { individual }\end{array}$ & Yes & Yes & Yes & Yes & Yes & Yes & Yes \\
\hline
\end{tabular}




\begin{tabular}{|c|c|c|c|c|c|c|c|}
\hline $\begin{array}{l}\text { Urban } \\
\text { household }\end{array}$ & Yes & Yes & Yes & Yes & Yes & Yes & Yes \\
\hline $\begin{array}{l}\text { Urban } \\
\text { community }\end{array}$ & $\begin{array}{l}\text { (Yes, } 2007 \text { in } \\
\text { correspondence } \\
\text { with migrant } \\
\text { samples) }\end{array}$ & Yes & Yes & No & Yes & No & No \\
\hline Rural individual & Yes & Yes & Yes & Yes & Yes & Yes & Yes \\
\hline Rural household & Yes & Yes & Yes & Yes & Yes & Yes & Yes \\
\hline $\begin{array}{l}\text { Rural } \\
\text { community }\end{array}$ & Yes (from 2002) & Yes & Yes & Yes & Yes & No & No \\
\hline $\begin{array}{l}\text { Migrant } \\
\text { individual }\end{array}$ & Yes (from 2002) & Yes & No & No & No & No & No \\
\hline $\begin{array}{l}\text { Migrant } \\
\text { household }\end{array}$ & Yes (from 2002) & Yes & No & No & No & No & No \\
\hline $\begin{array}{l}\text { Method of } \\
\text { collecting } \\
\text { income data }\end{array}$ & $\begin{array}{l}\text { Household } \\
\text { bookkeeping } \\
\text { and interview } \\
\text { (urban and rural } \\
\text { samples), } \\
\text { interview } \\
\text { (migrant } \\
\text { samples) }\end{array}$ & $\begin{array}{l}\text { Household } \\
\text { bookkeeping } \\
\text { and interview } \\
\text { (urban and } \\
\text { rural samples), } \\
\text { interview } \\
\text { (migrant } \\
\text { samples) }\end{array}$ & Interview & Interview & Interview & Interview & $\begin{array}{l}\text { Interview (main } \\
\text { interview and } \\
\text { quarterly-basis } \\
\text { complementary } \\
\text { interviews) }\end{array}$ \\
\hline $\begin{array}{l}\text { Main host } \\
\text { Institution }\end{array}$ & $\begin{array}{l}\text { China Institute } \\
\text { for Income } \\
\text { Distribution } \\
\text { (CID), Beijing } \\
\text { Normal } \\
\text { University } \\
\text { (BNU) } \\
\text { http://www.ciidb } \\
\text { nu.org/ }\end{array}$ & $\begin{array}{l}\text { RUMiCI } \\
\text { project, the } \\
\text { Australian } \\
\text { National } \\
\text { University } \\
\text { http://rse.anu. } \\
\text { edu.au/rumici/ } \\
\text { and } \\
\text { CID, BNU }\end{array}$ & $\begin{array}{l}\text { The Carolina } \\
\text { Population } \\
\text { Center, the } \\
\text { University of } \\
\text { North Carolina } \\
\text { at Chapel Hill } \\
\text { http://www.cpc. } \\
\text { unc.edu/projects } \\
\text { /china }\end{array}$ & $\begin{array}{l}\text { National Survey } \\
\text { Research } \\
\text { Center, Renmin } \\
\text { University of } \\
\text { China (RUC) } \\
\text { http://www.chin } \\
\text { agss.org/ }\end{array}$ & $\begin{array}{l}\text { Institute of } \\
\text { Social Science } \\
\text { Survey, Peking } \\
\text { University } \\
\text { http://www.isss. } \\
\text { edu.cn/cfps/ }\end{array}$ & $\begin{array}{l}\text { Institute of Social } \\
\text { Science Survey, } \\
\text { Peking University } \\
\text { http://charls.ccer. } \\
\text { edu.cn/zh-CN }\end{array}$ & $\begin{array}{l}\text { The Survey and } \\
\text { Research Center } \\
\text { for China } \\
\text { Household } \\
\text { Finance (CHFS), } \\
\text { Southwestern } \\
\text { University of } \\
\text { Finance and } \\
\text { Economics } \\
\text { (SWUFE). } \\
\text { http://www.chfsdat }\end{array}$ \\
\hline
\end{tabular}




\begin{tabular}{|c|c|c|c|c|}
\hline & & & & a.org/ \\
\hline $\begin{array}{l}\text { Related data } \\
\text { archives }\end{array}$ & $\begin{array}{l}\text { Inter-university } \\
\text { Consortium for } \\
\text { Political and } \\
\text { Social Research } \\
\text { (ICSR) } \\
\text { www.icpsr.umic } \\
\text { h.edu/ } \\
\text { The Universities } \\
\text { Service Centre } \\
\text { for China } \\
\text { Studies (USC), } \\
\text { the Chinese } \\
\text { University of } \\
\text { Hong Kong } \\
\text { (CUHK) } \\
\text { http://www.usc.c } \\
\text { uhk.edu.hk/Eng/ } \\
\text { Default.aspx }\end{array}$ & $\begin{array}{l}\text { International } \\
\text { Data Service } \\
\text { Center } \\
\text { (IDSC), IZA } \\
\text { idsc.iza.org }\end{array}$ & $\begin{array}{l}\text { Chinese Social } \\
\text { Survey Open } \\
\text { Database } \\
\text { (CSSOD), RUC } \\
\text { http://www.csso } \\
\text { d.org/index.php) } \\
\text { USC, CUHK }\end{array}$ & \\
\hline
\end{tabular}

Sources: Eichen and Zhang (1993), Griffin and Zhao (1993), Gustafsson et al. (2008), Li et al. (2008), Li et al. (2013), Luo et al. (2013), Riskin et al. (2001), Treiman et al. (2009), and official websites of main host institutions listed above. 
Table 2 Sample structure of the CHIP surveys

\begin{tabular}{|c|c|c|c|c|c|c|}
\hline & \multicolumn{3}{|c|}{1988} & \multicolumn{3}{|c|}{1995} \\
\hline $\begin{array}{l}\text { Household } \\
\text { category }\end{array}$ & Urban & Rural & $\begin{array}{l}\text { Rural- } \\
\text { urban } \\
\text { migrant }\end{array}$ & Urban & Rural & $\begin{array}{l}\text { Rural- } \\
\text { urban } \\
\text { migrant }\end{array}$ \\
\hline Individuals & 31827 & 51352 & -- & 21694 & 34739 & -- \\
\hline Households & 9009 & 10258 & -- & 6931 & 7998 & -- \\
\hline Provinces & 10 & 28 & -- & 11 & 19 & -- \\
\hline & $\begin{array}{c}\text { Beijing, Liaoning, } \\
\text { Jiangsu, } \\
\text { Guangdong, } \\
\text { Shanxi, Anhui, } \\
\text { Henan, Hubei, } \\
\text { Yunnan, Gansu }\end{array}$ & $\begin{array}{l}\text { Beijing, Tianjin, } \\
\text { Shanghai, Hebei, } \\
\text { Liaoning, Jiangsu, } \\
\text { Zhejiang, Fujian, } \\
\text { Shandong, } \\
\text { Guangdong, } \\
\text { Hainan, Shanxi, } \\
\text { Jilin, Heilongjiang, } \\
\text { Anhui, Jiangxi, } \\
\text { Henan, Hubei, } \\
\text { Hunan, Inner } \\
\text { Mongolia, } \\
\text { Guangxi, Sichuan, } \\
\text { Guizhou, Yunnan, } \\
\text { Shaanxi, Gansu, } \\
\text { Qinghai, Ningxia }\end{array}$ & & $\begin{array}{c}\text { Beijing, } \\
\text { Liaoning, } \\
\text { Jiangsu, } \\
\text { Guangdong, } \\
\text { Shanxi, Anhui, } \\
\text { Henan, Hubei, } \\
\text { Sichuan, } \\
\text { Yunnan, Gansu }\end{array}$ & $\begin{array}{c}\text { Beijing, Hebei, } \\
\text { Liaoning, Jiangsu, } \\
\text { Zhejiang, } \\
\text { Shandong, } \\
\text { Guangdong, } \\
\text { Shanxi, Jilin, } \\
\text { Anhui, Jiangxi, } \\
\text { Henan, Hubei, } \\
\text { Hunan, Sichuan, } \\
\text { Guizhou, Yunnan, } \\
\text { Shaanxi, Gansu }\end{array}$ & \\
\hline & \multicolumn{3}{|c|}{2002} & \multicolumn{3}{|c|}{2007} \\
\hline $\begin{array}{l}\text { Household } \\
\text { category }\end{array}$ & Urban & Rural & $\begin{array}{l}\text { Rural- } \\
\text { urban } \\
\text { migrant }\end{array}$ & Urban & Rural & $\begin{array}{l}\text { Rural- } \\
\text { urban } \\
\text { migrant }\end{array}$ \\
\hline Individuals & 21696 & 34719 & 5327 & 29262 & 51847 & 8404 \\
\hline Households & 6934 & 7998 & 2005 & 10000 & 13000 & 4978 \\
\hline Provinces & 12 & 22 & 12 & 16 & 16 & 9 \\
\hline & $\begin{array}{c}\text { Beijing, } \\
\text { Liaoning, } \\
\text { Jiangsu, } \\
\text { Guangdong, } \\
\text { Shanxi, Anhui, } \\
\text { Henan, Hubei, } \\
\text { Sichuan, } \\
\text { Chongqing, } \\
\text { Yunnan, Gansu }\end{array}$ & $\begin{array}{c}\text { Beijing, Hebei, } \\
\text { Liaoning, Jiangsu, } \\
\text { Zhejiang, } \\
\text { Shandong, } \\
\text { Guangdong, } \\
\text { Shanxi, Jilin, } \\
\text { Anhui, Jiangxi, } \\
\text { Henan, Hubei, } \\
\text { Hunan, Guangxi, } \\
\text { Sichuan, } \\
\text { Chongqing, } \\
\text { Guizhou, Yunnan, } \\
\text { Shaanxi, Gansu }\end{array}$ & $\begin{array}{r}\text { Beijing, } \\
\text { Liaoning, } \\
\text { Jiangsu, } \\
\text { Guangdo } \\
\text { ng, } \\
\text { Shanxi, } \\
\text { Anhui, } \\
\text { Henan, } \\
\text { Hubei, } \\
\text { Sichuan, } \\
\text { Chongqin } \\
\text { g, } \\
\text { Yunnan, } \\
\text { Gansu }\end{array}$ & $\begin{array}{c}\text { Beijing, } \\
\text { Shanghai, } \\
\text { Liaoning, } \\
\text { Jiangsu, } \\
\text { Zhejiang, } \\
\text { Fujian, } \\
\text { Guangdong, } \\
\text { Shanxi, Anhui, } \\
\text { Henan, Hubei, } \\
\text { Hunan, } \\
\text { Sichuan, } \\
\text { Chongqing, } \\
\text { Yunnan, Gansu }\end{array}$ & $\begin{array}{c}\text { Beijing, Hebei, } \\
\text { Liaoning, Jiangsu, } \\
\text { Zhejiang, Fujian, } \\
\text { Guangdong, } \\
\text { Shanxi, Anhui, } \\
\text { Henan, Hubei, } \\
\text { Hunan, Sichuan, } \\
\text { Chongqing, } \\
\text { Yunnan, Gansu }\end{array}$ & $\begin{array}{r}\text { Shanghai, } \\
\text { Jiangsu, } \\
\text { Zhejiang, } \\
\text { Guangdon } \\
\text { g, Anhui, } \\
\text { Henan, } \\
\text { Hubei, } \\
\text { Sichuan, } \\
\text { Chongqin } \\
\text { g }\end{array}$ \\
\hline
\end{tabular}

Sources: Eichen and Zhang (1993), Griffin and Zhao (1993), Gustafsson et al. (2008), Li et al. (2008), Li et al. (2013), Luo et al. (2013), Riskin et al.(2001). 